\title{
ATIVISMO JUDICIAL: UMA LEGITIMIDADE NECESSÁRIA OU UMA NECESSIDADE LEGÍTIMA?
}

\author{
Alyne Mendes Caldas ${ }^{1}$
}

\section{RESUMO}

Trata-se de análise sobre a legitimidade do Poder Judiciário para atuar de forma proativa ao exercer a função jurisdicional. Questiona-se, portanto, se é possível a existência legítima de ativismo judicial em um Estado de Direito pautado na teoria da separação dos poderes. Objetiva-se discutir a legitimidade da postura proativa do Poder Judiciário diante de conflitos que ultrapassam os limites da norma. Adota-se o método dedutivo bem como a pesquisa explicativa e a pesquisa bibliográfica. Analisa-se, por fim, a possibilidade da discricionariedade judicial constituir instrumento legítimo na garantia de direitos fundamentais no Estado Democrático de Direito.

Palavras-chaves: Estado Democrático de Direito, Ativismo Judicial, Separação de poderes, Legitimidade, direitos fundamentais

\section{JUDICIAL ACTIVISM: A NECESSARY LEGITIMACY OR A LEGITIMATE NEED?}

\begin{abstract}
It is about the Judiciary's legitimacy and judicial activism. Asking about the possibility to exist the judicial activism in Constitucional State to respect the theory on the separation of powers. The main goal is to discuss the legitimacy of the judicial rulings suspected. The deductive method is adopted as well as the explanatory research and the bibliographical research. Finally, it's examined whether the judicial activism can be a legitimate arm to protect the fundamental rights in the Democratic State of Law.
\end{abstract}

Keywords: Democratic State of Law, Judicial Activism, Theory on separation of power, Legitimacy, the fundamental rights

\section{INTRODUÇÃO}

No final do século XX, com o término das duas guerras mundiais o Ocidente se torna palco de uma mudança de paradigma constitucional. A Constituição que deixa de ser um documento meramente político e torna-se um instrumento jurídico com força normativa,

\footnotetext{
${ }^{1}$ Doutoranda em Ciências Jurídicas pela Universidade Autônoma de Lisboa - UAL. Mestre em Direito e Instituições do Sistema de Justiça pela Universidade Federal do Maranhão - UFMA. Professora Universitária. Advogada. E-mail: alyneinter@yahoo.com.br.
} 
dotada, portanto, de imperatividade, estabelecendo direitos e obrigações aos particulares bem como ao próprio Estado.

Além disso, percebe-se que o juiz possui uma atividade bem mais complexa do que a de mero reprodutor da lei. Afinal, a função judiciária possui uma liberdade de escolha bem maior do que aquela reconhecida pela maioria dos Estados no século XIX, sendo dotado, portanto, de uma discricionariedade judicial.

O ativismo judicial decorre dessa mudança de paradigma da função judiciária que exige do magistrado uma atuação mais proativa, não restrita à letra da lei.

Por essa razão, o presente trabalho tem como objetivo estudar a legitimidade do poder Judiciário para realizar o fenômeno do ativismo judicial em um Estado de Direito organizado com base na teoria da tripartição de poderes de Montesquieu.

Para tanto, a metodologia adotada consiste no método dedutivo no qual se trabalha uma cadeia de raciocínio descendente, da análise geral para a particular. Enquanto técnica de pesquisa, realizou-se uma pesquisa explicativa ao passo que se objetivou explicar os fatores que determinam o fenômeno do ativismo judicial bem como uma pesquisa bibliográfica já que houve um levantamento bibliográfico a partir de livros e artigos científicos para a construção de conceitos bases e para a elaboração dos argumentos apresentados.

No primeiro capítulo, analisa-se a formação do Estado de Direito e a trajetória que o mesmo percorreu até o século XX quando se percebe a mudança de paradigma da função judiciária, apresentando as razões para tal transformação no Poder Judiciário.

Já no segundo, discute-se acerca da legitimidade do Poder Judiciário para atuar de forma proativa no exercício da função judiciária a partir de um sistema jurídico de normas.

E no último capítulo, discute-se em que medida o ativismo judicial constitui instrumento legítimo de garantia das liberdades públicas.

\section{ESTADO DE DIREITO E A MUDANÇA DE PARADIGMA DA FUNÇÃo JUDICIÁRIA}

Tem-se por sociedade a união moral de seres racionais e livres, organizados de forma estável e eficaz para realizar um fim comum e conhecido por todos. (AZAMBUJA, 2008, p.18) A forma de ordenação dos homens em sociedade tem variado ao longo da história da humanidade. Nos seus primórdios, o homem organizava-se de forma simples, sua sociedade se resumia ao seu núcleo familiar. Hoje, no século XXI, as sociedades, em regra, organizam-se 
sob a forma de Estados.

Por isso Azambuja afirma que os Estados, nada mais são, do que sociedades ao passo que se constituem essencialmente de um grupo de indivíduos unidos e organizados permanentemente para realizar um objetivo comum. (AZAMBUJA, 2008, p.18) Porém, Estado como sinônimo de centralização do poder de forma soberana é uma locução política da Modernidade que deu seus primeiros passos por meio das revoluções iluministas marcadas pelo culto à razão e ao indivíduo em detrimento da crença e do transcendental que caíram por terra junto com a Idade Média.

O Estado Moderno surge, portanto, com a consolidação da soberania, sua principal característica. Tal fato era tido como inovador, pois, até então, a humanidade - pelo menos a parcela ocidental- ainda não tinha vivenciado uma ordem oriunda de um poder único, soberano. Tanto na Idade Média, quanto nos períodos anteriores coexistiram centros distintos de poderes que disputavam sua prevalência uns sobre os outros: cidades-estados e os povos conquistados, o rei e os senhores feudais, os camponeses e seus senhores.

Inicialmente, esse poder soberano foi atribuído à pessoa do governante, do monarca, do príncipe, espécie de divindade temporal e terrena que dissolvera num lento processo os diversos poderes desiguais e privilegiados do sistema feudal até se transformar no soberano absoluto de onde se irradiavam todas as competências e atribuições governativas (BONAVIDES, 2010, p. 35-36).

Vivia-se, assim, o absolutismo monárquico legitimado pelo poder divino, porém teorizado por autores racionais como Thomas Hobbes e Maquiavel. Ambos afirmaram que a ordem era sinônima de poder soberano absoluto. O soberano, portanto, seria o único capaz de livrar todos da ameaça do hipotético estado de natureza, da guerra de todos contra todos.

Entretanto, a abusividade característica do poder absolutista constituiu mau irreparável ao Estado Absolutista. Os direitos naturais - em especial a liberdade - não encontravam guarida no governo dos soberanos que era movido por paixões e não pela razão. Com a ascensão de uma nova classe emergente, a burguesia, a tolerância aos abusos dos monarcas foi diminuindo na mesma proporção do seu fortalecimento econômico.

Bonavides bem coloca que a burguesia foi favorecida pelas políticas mercantilistas e expansão colonialista das grandes potências europeias rivais. Essa classe se tornou o centro e o eixo vital da sociedade. Aliada primeiramente à monarquia absoluta da qual se separou para monopolizar o poder, que, uma vez limitado pelas formas representativas, permitiu que a 
burguesia pudesse exercer o poder político em proveito próprio. (BONAVIDES, 2010, p.37)

Para tanto era necessário, uma nova estrutura para o Estado. Uma engrenagem não mais fundada na metafísica e no transcendental, mas sim na previsibilidade e no controle que só era possível se obter pela razão. Assim o fez a classe burguesa em todo o mundo após conquistar os postos mais elevados do Estado.

Os ingleses iniciaram tal processo com a edição da Carta Magna, pelo rei João sem terra em 1215. Tal documento foi a primeira manifestação formal de limitação do poder soberano e até então, absoluto do Estado. Com a consolidação do Parlamento inglês - composto pela nobreza e pela burguesia - como representantes populares, os poderes da monarquia foram restringidos em nome dos interesses dos cidadãos a partir da edição de diversas cartas de direitos como a Bill of Rights ${ }^{2}$ e Petition of Rights ${ }^{3}$.

Percebe-se que a razão vai dominando as engrenagens governamentais na medida em que as leis oriundas da vontade popular, representada pelo Parlamento, passam a ser o instrumento maior de controle das ações governamentais. Leis essas que visavam à limitação do poder do Estado e a proteção dos direitos naturais do homem como a liberdade e a igualdade.

Nos Estados Unidos da América, pela primeira vez na história da humanidade, a soberania popular converteu-se em supremacia da Constituição. Em solo ianque, foi elaborada a primeira Constituição escrita ${ }^{4}$ do mundo que veio sedimentar um Estado fundado na liberdade e na democracia ${ }^{5}$.

Por isso, a Constituição americana não apenas consolidou a primazia da lei na condução social como criou um Estado de Direito com diversas inovações para garantir a consecução da liberdade e da democracia, principalmente por acreditarem que o progresso só

\footnotetext{
${ }^{2}$ A Bill of Rights (Declaração de Direitos) previa a convocação regular do Parlamento, de cujo consentimento dependiam medidas como a criação de leis, a instituição de tributos e a manutenção de exército permanente em tempos de paz. Assegurava ainda imunidade aos parlamentares por suas manifestações no Parlamento e impedia a aplicação de pena sem prévio julgamento. (BARROSO, 2011, p.33)

${ }^{3}$ A Petição de Direitos (Petition of Rights) protestava contra o lançamento de tributos sem aprovação do Parlamento, as prisões arbitrárias, o uso da lei marcial em tempos de paz e a ocupação de casas particulares por soldados. (BARROSO, 2011, p.33)

${ }^{4}$ Constituição escrita significa a organização das normas e princípios em um único documento elaborado solenemente.

5 "Como se sabe, os americanos do norte tiveram um processo de colonização muito peculiar. Na verdade, Londres não empreendeu esforços para colonizar as terras americanas. Foram os próprios ingleses que, por questões pessoais, resolveram migrar para essas novas terras e lá construir as suas vidas. Mesmo diante desse processo, a metrópole praticava algumas interferências na vida dos colonos americanos, os quais as aceitavam em certa medida, desde que não fizessem alusão à cobrança de impostos e fossem convenientes para reconhecer direitos que lhes pertenciam por serem súditos ingleses, não só frente aos possíveis abusos dos poderes da Inglaterra, como também frente aos excessos dos poderes locais ". (RAMOS, 2012, p. 13-14 ).
} 
era possível se cada homem fosse livre para explorar seu potencial plenamente. Federalismo, presidencialismo, separação rígida dos poderes e a supremacia da Constituição são alguns exemplos de institutos positivados de forma inédita pela Constituição americana de 1787, em vigor até hoje $e^{6}$.

Os protagonistas do constitucionalismo norte-americano assim como na França foram burgueses. Sua prosperidade estava sendo prejudicada pelo vínculo que subsistia entre as colônias americanas e a coroa inglesa, logo, os homens livres e prósperos da América vislumbraram na independência norte-americana a oportunidade perfeita para a criação de um Estado que fosse favorável à liberdade e, por consequência, ao progresso ${ }^{7}$.

Os franceses, por sua vez, tiveram uma missão mais árdua já que enquanto os americanos tiveram que guerrear contra um regime monárquico que se desenvolveu a um oceano de distância da América. A França foi alvo de toda a Europa. Os inimigos moravam ao lado. (TOCQUEVILLE, 1998, p.91-92) A Revolução Francesa que lá se desenrolou significou o fim do Antigo Regime, sendo a Declaração dos Direitos do Homem e do Cidadão de $1789^{8}$ o seu atestado de óbito. (BOBBIO, 2004, p.100)

Assim, com a Revolução Francesa iniciou-se uma nova época da história, com uma explícita referência à Declaração cuja finalidade era firmar os direitos humanos, dentre os quais, destacam-se a liberdade e a igualdade diante da lei, enquanto posterior determinação. (BOBBIO, 2004, p.101).

O novo regime que surgiu com a Revolução Francesa, assim como o americano, foi fundado na supremacia constitucional. A elaboração da primeira Constituição francesa foi em

\footnotetext{
${ }^{6}$ A Constituição americana de 1787 foi produto de um trabalho teórico, pautado na razão no qual foram discutidos e ponderados problemas e soluções mais adequadas às necessidades da sociedade americana, sempre tendo em mente a guarida maior dos direitos fundamentais. Essa percepção é retratada por Alexy de Tocqueville ao afirmar "o que é novo na história das sociedades é ver um grande povo, informado pelos seus legisladores de que as engrenagens do governo estão emperradas, voltar a olhar para si mesmo, sem precipitação nem temor, e sondar a profundeza "do mal, conter-se durante dois anos inteiros, a fim de descobrir com vagar o seu remédio e, uma vez indicado esse remédio, submeter-se a ele voluntariamente, em que custe uma lágrima nem uma gota de sangue à humanidade". (TOCQUEVILLE, 1998, p. 92.)

7 "Ademais, também já tinha grande aceitação entre os americanos a ideia consoante a qual certos direitos são inerentes às pessoas e que a finalidade de qualquer poder é unicamente garantir o seu respeito”. (RAMOS,2012, p. 14 )

8 “(...) Constatou-se então com irrecusável veracidade que as declarações antecedentes de ingleses e americanos podiam talvez ganhar em concretude, mas perdiam em espaço de abrangência, porquanto se muito a um povo ou a uma sociedade que se libertava politicamente, conforme era o caso das antigas colônias americanas, ao passo que a Declaração francesa de 1789 tinha por destinatário o gênero humano. Por isso mesmo, e pelas condições da época, foi a mais abstrata de todas as formulações solenes já feitas acerca da liberdade. Os direitos do homem ou da liberdade, se assim podemos exprimi-los, eram ali 'direitos naturais, inalienáveis e sagrados', direitos tidos também por imprescritíveis, abraçando a liberdade, a propriedade, a segurança e a resistência à opressão". (BONAVIDES, 2004, p.562.)
} 
1791, na primeira fase da revolução que foi de 1789 a 1792, na qual se consumou o fim do Antigo Regime e se pretendeu criar uma monarquia constitucional e parlamentar em que o rei deixava de ser soberano por direito próprio e passava a ser delegado da nação. (BARROSO,2011, p.48)

Assim, percebe-se que diante de um mundo tão hostil, tanto em face da natureza quanto em relação a seus semelhantes, o homem buscou reagir inventando técnicas de sobrevivência em relação à primeira, e de defesa em relação à segunda. Estas últimas são representadas pelos sistemas de regras que reduzem os impulsos agressivos mediante penas ou estimulam os impulsos de colaboração e de solidariedade através de prêmios. (BOBBIO, 2004, p.72) Tais sistemas de regras, rígidas e herméticas de cunho jurídico-social, a partir do constitucionalismo moderno, passaram a ser de monopólio do chamado Estado de Direito.

Assim, a Constituição, como norma suprema, no ápice do ordenamento jurídico pressuposto de validade de todas as outras normas jurídicas - com base no normativismo jurídico kelseniano - se torna a principal fonte de regulação social.

A norma suprema passa também a veicular os limites da atuação do Estado tendo como objetivo basilar a proteção das liberdades públicas dos cidadãos. Dentre os limites constitucionais encontram-se as limitações organizacionais por meio das quais as funções estatais devem ser exercidas por órgãos distintos seguindo a teoria da separação dos poderes de Montesquieu em maior ou menor medida ${ }^{9}$.

Charles-Louis de Secondat, o Barão de Montesquieu em seu livro "O espírito das leis" estabeleceu uma teoria da tripartição dos poderes do Estado a partir das suas funções Executiva (função executiva), Legislativa (função legislativa) e Judiciária (função jurisdicional) que se ligam a órgãos distintos, autônomos e independentes entre si, estabelecidos em lei que como bem coloca o professor Alex Sander Xavier Pires:

\begin{abstract}
Como se exige uma atuação eficaz de cada função, deve-se ter em mente seus núcleos de ação: legiferar significa ter o poder de criar leis em sentido geral (para tudo que exija regulamentação) e universal (para todos sem distinção, mas tendo a justiça como limite); administrar representa cuidar da coisa comum, praticando políticas públicas hábeis a entregar ao povo os bens sociais prometidos na Constituição; e jurisdicionar impõe o dever de pacificar o conflito de interesses dizendo a quem pertence o direito litigado e vias de entregar o bem jurídico tutelado." (PIRES, 2016, p. 185)
\end{abstract}

\footnotetext{
9 "No início do século XIX, a maior parte do pensamento jurídico tinha-se convertido ao princípio da separação dos orgânico-pessoal entre poder legislativo e executivo, entre legislativo e judicial e entre executivo e judicial. (...) Governar/Administrar passou a ser sinónimo de agir, ou seja, levar a efeito todo um conjunto de acções de interesse comum à sociedade política enquanto que a jurisdição se reduziu a uma atividade eminentemente intelectual confinada à declaração, no caso concreto, daquilo que a lei tinha previsto em termos gerais". (AFONSO, 2004, p. 36)
} 
Percebe-se que Montesquieu objetivou atribuir à lei a autoridade maior para conduzir o Estado, temendo que o homem permanecesse refém da vontade de um ou de alguns poucos, vivendo em estado de desconfiança permanente. Com a instituição do Estado de Direito, o homem passou a buscar segurança no Direito e acreditou, assim, conquistar a tão almejada liberdade política, como descreve Montesquieu:

\begin{abstract}
A liberdade política, num cidadão, é essa tranquilidade de espírito que provém da opinião que cada qual tem de sua segurança; e, para que tenhamos essa liberdade, o governo deve ser tal, que um cidadão não possa temer outro cidadão. (...) Tudo estaria perdido se o mesmo homem ou o mesmo corpo de principais ou de nobres ou do povo exercesse estes três poderes: o de fazer as leis, o de executar as resoluções públicas e o de julgar os crimes ou litígios dos particulares. (MONTESQUIEU, 2010, p.169).
\end{abstract}

Essa foi a matriz da teoria da separação de poderes de Montesquieu, porém foi na obra, Os Federalistas, que o Alexander Hamilton, no capítulo LI, chama atenção para a dinâmica dessa separação de funções do Estado:

A que meio se recorrerá portanto para manter na pratica esta separação essencial dos
poderes que a constituição estabelece em teoria? Como todos os remédios exteriores
são sem effeito, não ha outro remedio possível senão traçar de tal maneira a
construcção do governo, que todas as suas differentes partes possão reter-se humas ás
outras nos seus lugares respectivos. ( HAMILTON,MADSON, JAY, 1840, p. 216)

Vê-se que não bastava a divisão das funções estatais entre órgãos diferentes: Legislativo, Executivo e Judiciário. Era necessário estabelecer uma relação de equilíbrio entre esses órgãos de maneira que eles se tornassem verdadeiros freios e contrapesos uns dos outros. Surge, portanto, o princípio do checks and balances em complemento à teoria tripartite de Montesquieu, como descrito por Hamilton, no trecho abaixo:

Porém o verdadeiro meio de embaraçar que os differentes poderes se não vão
successivamente accumulando nas mesmas mãos, consiste em dar áquelles que os
exercitão meios sufficientes e interesse pessoal para resistir ás usurpações. Neste caso,
como em todos os outros, os meios de defensa devem ser proporcionados aos perigos
do attaque; he preciso oppôr ambição, e travar tal modo o interesse dos homens com
as obrigações que lhes impoem os direitos constitucionaes dos seus cargos, que não
possão ser offendidas as ultimas sem que o primeiro padeça. He desgraça inherente á
natureza humana a necessidade de taes meios; mas já a necessidade dos governos he
em si mesma huma desgraça. Se os homens fossem anjos, não haveria necessidade de
governo; e se anjos governassem os homens, não haveria necessidade de meio algum
externo ou interno para regular a marcha do governo: mas quando o governo he feito
por homens e administrado por homens, o primeiro problema he pôr o governo em
estado de poder dirigir o procedimento dos governados, e o segundo obriga-lo a
cumprir as suas obrigações. A dependencia em que o governo se acha do povo he
certamente o seu primeiro regulador; mas a insufficiencia deste meio está
demonstrada pela experiencia. (HAMILTON,MADSON, JAY, 1840, p. 217-218)

O povo embora seja elemento legitimador do poder do Estado, não constitui um limite suficiente para exercer um controle efetivos sobre os poderes Legislativo, Executivo e 
Judiciário. Hamilton, portanto, observa que deveria haver um sistema de controle mutuo entre os poderes, proporcionais a capacidade de subversão desses mesmos poderes.

A junção da teoria da separação dos poderes do Estado e a teoria do check and balances consistiu na base político-institucional de grande parte dos Estados instituídos a partir do final do século XVIII, incluindo o Brasil com a instituição do Estado Federal Republicano de 1891.

No final do século XX, após as duas guerras mundiais vivencia-se no Ocidente uma mudança de paradigma constitucional. Vê-se um fortalecimento da própria Constituição que deixa de ser um norte meramente político e torna-se um instrumento jurídico com força normativa ${ }^{10}$ própria, capaz de estabelecer direitos e obrigações aos particulares bem como ao próprio Estado, como:

(...) a vontade social abstraída da razão ponderada dos indivíduos que lhe compõem, em tom de igualdade - com o mesmo valor - e de liberdade - sem restrição de aspirações-, para conjugar o sentimento de estar em Constituição (sentimento constitucional) com o dever de cumprimento de seus dispositivos (força normativa).” (PIRES, 2016, p. 184)

Essa mudança reflete uma verdadeira "revolta contra o formalismo" (WHITE, M.G 1949 apud CAPPELLETTI, 1993, p.31 ), o que propiciou uma volta dos valores de justiça para o campo do direito. Exige-se que as normas jurídicas reguladoras de condutas sociais não se restrinjam mais às regras fechadas e rígidas cuja modificação só seria possível por meio de processos complexos de alteração, de responsabilidade exclusiva do Legislativo. Como Mauro Cappelletti bem descreve quando afirma que:

É bem compreensível que, nas diferentes partes do mundo, tal revolta tenha visado a alvos diversos. Enquanto, nos Estados Unidos e, de forma talvez mais acentuada, em outros ordenamentos de Common Law, cuidou-se essencialmente da revolta contra o formalismo do case method, em França e nas áreas de influência francesa dirigiu-se, pelo contrário, sobretudo contra o positivismo jurídico, enquanto na Alemanha e áreas de influência alemã representou principalmente uma insurgência contra o formalismo “científico" e conceitual. (CAPPELLETTI, 1993, p. 31-32)

Ora, a velocidade das transformações sociais no final do século XX e início do século XXI exigiu uma revisão nas estruturas formais do sistema de justiça - oriundas do século XIX

\footnotetext{
${ }^{10}$ No presente trabalho, parte-se do pressuposto da força normativa da Constituição seguindo a teoria do professor alemão Konrad Hesse pela qual o documento constitucional possui força normativa que lhe atribui uma imperatividade que torna possível estabelecer uma relação dialógica com a sociedade, visando manter a efetividade diante das demandas sociais como se pode inferir do trecho a seguir: "a norma constitucional somente logra atuar se procura construir o futuro com base na natureza singular do presente. [...] a força vital e a eficácia da Constituição assentam-se na sua vinculação às forças espontâneas e às tendências dominantes do seu tempo, o que possibilita o seu desenvolvimento e a sua ordenação objetiva. A Constituição converte-se, assim, na ordem geral objetiva do complexo de relação da vida". (HESSE, 1991, p. 18).
} 
- cuja eficiência se tornou duvidosa.

Ademais, com o pós-guerra constrói-se consensos mundiais - ou pelo menos, tenta- se - acerca de valores de proteção ao ser humano que foram constitucionalizados paulatinamente pelos Estados soberanos, em especial, no Ocidente ${ }^{11}$.

Verificou-se, assim, um fortalecimento da atuação jurisdicional, como bem afirma o ministro do Supremo Tribunal Federal Luís Roberto Barroso:

\begin{abstract}
O fenômeno é universal e também está conectado ao final da Segunda Grande Guerra. A partir daí o mundo deu-se conta de que a existência de um Poder Judiciário independente e forte é um importante fator de preservação das instituições democráticas e dos direitos fundamentais. No Brasil, sob a vigência da Constituição de 1988, o Judiciário, paulatinamente, deixou de ser um departamento técnico especializado do governo para se tornar um verdadeiro poder político. Com a redemocratização, aumentou a demanda por justiça na sociedade e, consequentemente, juízes e tribunais foram crescentemente chamados a atuar, gerando uma judicialização ampla das relações sociais no país. Esse fato é potencializado pela existência, entre nós, de Constituição abrangente, que cuida de ampla variedade de temas". (BARROSO, 2015, p. 28/29)
\end{abstract}

Percebe-se que o juiz possui uma atividade muito mais complexa do que ser um simples "boca da lei”, posto que é bem mais responsável por suas decisões do que haviam sugerido as teorias tradicionais (CAPPELLETTI, 1993, p. 33). A função judiciária, portanto, é dotada de uma liberdade de escolha bem maior do que aquela reconhecida pela maioria dos Estados no século XIX, não podendo mais o magistrado se furtar de tal responsabilidade, como bem explica CAPPELLETTI:

E assim o juiz não pode mais se ocultar, tão facilmente, detrás da frágil defesa da concepção do direito como norma preestabelecida, clara e objetiva, na qual pode basear sua decisão de forma "neutra". É envolvida sua responsabilidade pessoal, moral e política, tanto quanto jurídica, sempre que haja no direito abertura para escolha diversa. E a experiência ensina que tal abertura sempre ou quase sempre está presente. (CAPPELLETTI, 1993, p. 33)

Demonstra-se, desta forma, uma mudança de paradigma da função judiciária que foi estabelecida originariamente como uma função rígida e hermética que se restringia a

\footnotetext{
11 "No plano doméstico, os países procuram administrar, da forma possível, a diversidade que caracteriza a sociedade contemporânea, marcada pela multiplicidade cultural, étnica e religiosa. $\mathrm{O}$ respeito e a valorização das diferenças encontram-se no topo da agenda dos Estados democráticos e pluralistas. Buscam-se arranjos institucionais e regimes jurídicos que permitam a convivência harmoniosa entre diferentes, fomentando a tolerância e regras que permitam que cada um viva, de maneira não excludente, as suas próprias convicções. Ainda assim, não são poucas as questões suscetíveis de gerar conflitos entre visões de mundo antagônicas. No plano internacional, elas vão de mutilações sexuais à imposição de religiões oficiais e conversões forçadas. No plano doméstico, em numerosos países, as controvérsias incluem o casamento de pessoas do mesmo sexo, a interrupção da gestação e o ensino religioso em escolas públicas. Quase tudo transmitido ao vivo, em tempo real. A vida transformada em reality show." (BARROSO, 2015, p. 31)
} 
julgamentos fixos a tal ponto, "que não seriam senão um texto preciso da lei" (MONTESQUIEU, 2010, p.170).

Hoje, com as novas demandas sociais, foi necessário romper com a ilusão de que o juiz se encontra em posição de apenas "declarar" o direito utilizando apenas a lógica dedutiva, sem envolver nenhuma valoração pessoal. (CAPPELLETTI, 1993, p.33). Sendo imperativa uma atuação mais proativa do judiciário, mesmo em campos antes não percorridos - pelo menos, não expressamente - como a política e a economia, "dando vida a lei”, como dispõe PIRES:

Tal mudança institucional será possível repensando sua estrutura e atuação prática no sentido de "dar vida a lei", mediante: a supressão da inércia legislativa via afastamento das leis incompatíveis com o sistema atual e o preenchimento de lacunas, por técnicas de interpretação que esvaziem a escusa para a criação desordenada de normas jurídicas; ao mesmo tempo em que, como guardião e moderador dos poderes políticos, deva impor limites às práticas da Administração Pública. (PIRES, 2016, p. 214-15)

O ativismo judicial é, portanto, produto dessa mudança de paradigma da função judiciária que exige do magistrado uma atuação mais proativa, não restrita à letra da lei. Contudo, é necessário compreender melhor em que consiste o ativismo judicial e, principalmente, se o juiz é legítimo para atuar no processo de “criação do Direito".

\section{ATIVISMO JUDICIAL E A LEGITIMIDADE DA CRIATIVIDADE JURISPRUDENCIAL}

O ativismo judicial consiste em um fenômeno no qual há a participação mais ampla do judiciário na concretização das garantias e princípios constitucionais, fundados na dignidade da pessoa humana. Nessa mesma linha, o professor Inocêncio Coelho se posiciona:

Uma reflexão mais acurada, no entanto, acabará justificando certo incremento dessa criatividade - inclusive nos sistemas jurídicos de tradição continental -, chegando mesmo a evidenciar que essa suposta usurpação de poder se mostra indispensável para realizar a Constituição e tornar efetiva a defesa dos direitos fundamentais contra eventuais agressões do legislador. (COELHO, 2015, p. 5)

Essa postura mais proativa do Judiciário se justifica, em grande medida, pela retração do Poder Legislativo e do Poder Executivo em determinadas situações nas quais os mesmos não conseguem suprir as demandas sociais que lhes são impostas constitucionalmente, como bem explica Luís Roberto Barroso :

O ativismo judicial é uma atitude, a escolha de um modo especifico e proativo de interpretar a Constituição, expandindo o seu sentido e alcance. Normalmente, ele se instala em situações de retração do Poder Legislativo, de um certo deslocamento entre a classe política e a sociedade civil, impedindo que as demandas sociais sejam atendidas de maneira efetiva. A ideia de ativismo judicial está associada a uma 
participação mais ampla e intensa do judiciário na concretização dos valores e fins constitucionais, com maior interferência no espaço de atuação dos outros dois Poderes. A postura ativista se manifesta por meio de diferentes condutas, que incluem: (i) a aplicação direta da Constituição a situações não expressamente contempladas em seu texto e independentemente de manifestação do legislador ordinário; (ii) a declaração de inconstitucionalidade de atos normativos emanados do legislador, com base em critérios menos rígidos que os de patente e ostensiva violação da Constituição; (iii) a imposição de condutas ou de abstenções ao Poder Público, notadamente em matéria de políticas públicas. (BARROSO, 2009, p.3)

O ativismo judicial, portanto, é uma modalidade especial de atuação do Poder Judiciário que visa efetivar as demandas sociais de interesse da coletividade, não extrapolando os limites impostos pela Constituição Federal.

Em um primeiro momento, ao retomar as lições de Montesquieu sobre a tripartição dos poderes, pode-se pensar que o ativismo judicial seria um fenômeno diametralmente oposto aos propósitos da função judiciária, já que instiga o Poder Judiciário a atuar de forma criativa, inovando no ordenamento jurídico.

Contudo, essa função criativa do juiz em relação ao Direito, não é nenhuma novidade, posto que o ato de interpretar em si, é um ato criativo. Assim, como bem coloca AFONSO, a criatividade interpretativa abre espaço à discricionariedade da função judiciária, como dito a seguir:

O reconhecimento da criatividade conatural à interpretação da norma abre caminho à discricionariedade da atividade judicial, porém, discricionariedade não significa arbítrio. Significa tão somente, que o juiz pode escolher entre as várias alternativas interpretativas. Só que tal possibilidade de escolha resvala num segundo problema: a atividade judicial poderá tornar-se fonte de incerteza para quem dela se tem de socorrer. (AFONSO, 2004, p. 80)

Nessa mesma esteira, segue CAPPELLETTI, quando afirma que já não é mais possível considerar que o juiz como um mero reprodutor da lei formalmente criada pelo Legislador. Pelo contrário, explica que:

(...) o papel do juiz é muito mais difícil e complexo, e de que o juiz, moral e politicamente, é bem mais responsável por suas decisões do que haviam sugerido as doutrinas tradicionais. Escolha significa discricionariedade, embora não necessariamente arbitrariedade; significa valoração e "balanceamento"; significa ter presente os resultados práticos e as implicações morais da própria escolha; significa que devem ser empregados não apenas os argumentos da lógica abstrata, ou talvez os decorrentes da análise linguística puramente formal, mas também sobretudo aqueles da história e de economia, da política e da ética, da sociologia e da psicologia. (CAPPELLETTI, 1993, p. 33)

Diante disso, surge o questionamento sobre o que deu ensejo a essa mudança de paradigma entre o modelo preconizado por Montesquieu e o atual reconhecimento da liberdade criativa da função judiciária. CAPPELLETTI tenta trazer algumas luzes para essa questão, 
apontando possíveis razões.

A primeira delas está relacionada à radical mudança ocorrida no próprio papel do direito e do Estado na sociedade moderna a partir do fortalecimento do chamado welfare state que resultou em uma intensa atividade legislativa e, por consequência, no crescimento do papel do Estado em geral. (CAPPELLETTI, 1993, p. 35)

Segundo ponto que merece destaque foi o surgimento de normas programáticas relacionadas aos direitos sociais que trouxe para o ordenamento jurídico, em especial, para a Constituição normas abertas, de caráter vago. Essas espécies de normas atribuíram à função judiciária um caráter mais criativo, pela simples razão de quanto mais vaga a lei e mais imprecisos os elementos do direito, mais amplo se torna também o espaço deixado à discricionariedade nas decisões judiciárias. (CAPPELLETTI, 1993, p. 42)

Além disso, o autor aponta o Overload da função legislativa como uma das razões para as mudanças que ocorreram com a função judiciária. Isto porque para evitar paralisia, o legislativo viu a necessidade de transferir a outrem - executivo e seus órgãos auxiliares e derivados - grande parte de sua atividade, de maneira que suas ambições terminaram em abdicação. Assim, leis obsoletas bem como valores e prioridades dos políticos restritos à interesses particulares resultou em desilusão e desconfiança do Parlamento, tornando o welfare state uma verdadeira demagogia (CAPPELLETTI, 1993, p. 43).

A "emergência do estado administrativo", como bem lembrado pelo autor, trouxe consigo o perigo de abusos da burocracia a partir de uma "tutela" paternalista, quando não de opressão autoritária sobre os cidadãos por meio do "onipresente aparelho administrativo" inacessível e não orientado para o serviço público real o que acaba por gerar um sentimento de abandono e descaso na sociedade e, por consequência, a descrença na Administração Pública. (CAPPELLETTI, 1993, p. 45)

Último ponto destacado foi o problema da legitimação democrática do Estado, em especial, em relação aos agentes políticos. Diante da ausência de identidade entre a vontade do povo e a vontade manifestada pelos seus representantes por meio das leis e outros atos públicos, o cidadão se vê ainda mais incrédulo no sistema democrático representativo que constitui a base dos Poderes Legislativo e Executivo dos Estados Constitucionais. (CAPPELLETTI, 1993, p. 46)

Além disso, é importante destacar o problema da legitimidade da criatividade jurisprudencial. Ora, já restou demonstrado que a criatividade sempre fez parte da função 
judiciária, porém não era reconhecida enquanto tal, já que ao longo dos séculos XIX e grande parte do século XX, as sociedades acreditaram que o formalismo jurídico e, por consequência, a rigidez do modelo tradicional de tripartição de poderes eram suficientes para resolver todos os conflitos sociais. E que o poder legitimamente democrático só residia nas mãos do Executivo e Legislativo, sem a preocupação com o equilíbrio entre os poderes e a ressalva dos checks and balances $^{12}$. Isso, como bem explica CAPPELLETTI:

(...) teve como consequência um judiciário perigosamente débil e confinado, em essência, aos conflitos "privados". Esse ideal significou, assim, até época relativamente recente e mesmo hoje, em não poucos países, não só a existência de um legislativo totalmente não controlado, como de um executivo também praticamente não controlado, pelo menos até que se conseguisse desenvolver um autônomo sistema de justiça administrativa, a se impor como guardião da administração pública (CAPPELLETTI, 1993, p. 53)

Ademais, a separação rígida entre legislativo e executivo, mais do que contrapesos equilibrados, significou a passagem de períodos em que efetivamente o poder era concentrado nas assembleias legislativas, para ouros períodos em que, ao contrário, a concentração de poder ocorreu no executivo. (CAPPELLETTI, 1993, p. 53-54)

Sendo assim, é nítido que apenas um sistema equilibrado de controles recíprocos pode, sem perigo para a liberdade, fazer coexistir um legislativo forte com um executivo forte e um judiciário forte. (CAPPELLETTI, 1993, p. 54)

A criatividade da função judiciária é, portanto, corolário do sistema de freios e contrapesos, pois constitui instrumento hábil para conter a força majoritária caso venha a contradizer o sistema jurídico de normas capitaneado pela Constituição. O Poder Judiciário, desta feita, torna-se encarregado de defender os valores sociais que contra a vontade, por vezes, "caprichosa" da maioria quer contra o império das razões instrumentais e econômicas, apenas desejosas de eficácia. (AFONSO, 2004, p. 52)

Dessa maneira, verificar-se-á como o ativismo judicial pode ser tido como um instrumento de garantia das liberdades públicas, em especial, na consecução do direito fundamental da igualdade.

\footnotetext{
${ }^{12} \mathrm{O}$ sistema de checks and balances (freios e contrapesos) se justifica a partir da "constatação de que a formação de governos é típica dos homens que padecem com a vontade de avocar o poder - ambição -, de sorte que a própria estrutura deve ter condições de frear os ímpetos naturais para devolver-lhe, incólume, ao seu detentor legítimo, o povo, mediante políticas públicas que satisfaçam a vontade constitucional. ” (PIRES, 2016, p. 186-187)
} 


\section{ATIVISMO JUDICIAL COMO INSTRUMENTO DE GARANTIA DAS LIBERDADES PÚBLICAS}

Viu-se que o ativismo judicial é produto da mudança de paradigma da função judiciária, uma vez que significa o reconhecimento da função criativa do juiz. Isso porque no período pós-guerras mundiais emergiu um movimento constitucional no sentido de atribuir força normativa a valores tido como caros pela sociedade.

Nesse contexto, se deu a promulgação da Constituição Portuguesa de 1976, a Constituição brasileira de 1988, bem como, as constituições de grande parte dos Estados latinoamericanos e europeus.

Esses Estados Constitucionais externaram uma grande preocupação com a garantia dos direitos fundamentais de tal forma, que não bastava a Constituição trazer em seu bojo preceitos reconhecendo a existência de direitos fundamentais como liberdade, igualdade, propriedade, vida; era necessário ir além. Era necessário constitucionalizar instrumentos de proteção efetiva desses direitos.

Isso só foi possível a partir de consensos universais que passaram a ser estabelecidos por meio de tratados internacionais como a Declaração dos Direitos do Homem e do Cidadão de 1948, o Pacto dos direitos civis e políticos de 1966, Convenção Europeia dos Direitos Humanos de 1953, o Convenção Americana de Direitos Humanos de 1978 e entre outros instrumentos que traçaram compromissos entre os Estados de Direito de proteção ao ser humano nas mais diversas searas.

Os Estados de Direito que são instituídos a partir das Constituições do pós-guerra trouxeram, portanto, como valor basilar dos seus sistemas jurídicos a dignidade da pessoa humana com princípio jurídico-constitucional.

Dessa forma, a proteção ao ser humano adquire força normativa por meio do princípio da dignidade da pessoa humana o que significa uma maior preocupação com a garantia dos direitos fundamentais, como afirma, o professor Jorge Reis Novaes:

\footnotetext{
Assim, é relativamente pacífico que, pelo menos em sentido material, a dignidade da pessoa humana e o seu reconhecimento estão na própria base da consagração dos direitos fundamentais, designadamente, e de forma mais directa, nos direitos fundamentais especificamente dirigidos a garantir juridicamente a autonomia individual, a privacidade, a liberdade, a igualdade, o respeito e o bem-estar. (NOVAES, 2016, p. 28)
}

Ademais, o princípio da dignidade da pessoa humana apresenta como obstáculo à sua 
concretização a diversidade de alcance e sentidos que pode adquirir. Em virtude disso, é importante pontuar o objeto das disposições constitucionais que veiculam tal princípio o que NOVAES faz com maestria quando coloca:

\begin{abstract}
Estas (disposições constitucionais) referem-se primariamente, ainda que haja outros sentidos que possam ser igualmente retirados do acolhimento constitucional, à dignidade que é reconhecida a qualquer pessoa pelo simples facto de o ser e, portanto, é essa sua qualidade que é objeto do nosso interesse. (NOVAES, 2016, p.19)
\end{abstract}

Ora, se toda e qualquer pessoa é destinatária do princípio da dignidade da pessoa humana pelo mero fato de ser "ser humano", como garantir a dignidade diante da pluralidade de sujeitos e, por consequências, da pluralidade de conflitos sociais?

O Estado ainda constitui a principal via de proteção da dignidade da pessoa humana e, por consequência, de garantia dos direitos fundamentais por meio da Constituição. Verdadeiro pacto social que constitui escudo de proteção dos indivíduos contra os desmandos de particulares e do próprio Estado. Logo, os poderes do Estado possuem suas funções vinculadas a esse objetivo maior, como a seguir exposto:

Nessa qualidade, a dignidade da pessoa humana impõe-se juridicamente à observância de todos os poderes do Estado, vinculados que eles ficam, por força da recepção constitucional do princípio, ao seu respeito, à sua proteção e à sua promoção. (NOVAES, 2016, p. 18)

Como já demonstrado no capítulo anterior, nesse início do século XXI, os Estados de Direito, como Brasil, Itália, França e Portugal, vivenciam uma grave crise de representatividade dos poderes políticos do Estado (Executivo e Legislativo) na qual inexiste identidade entre a vontade do povo e a vontade manifestada pelos seus representantes por meio de leis e atos públicos de governo que significam os principais instrumentos de garantia dos direitos fundamentais, em especial, das liberdade públicas.

Diante disso, o ativismo judicial se torna uma via para efetivar o checks and balances, ou seja, efetivar um real equilíbrio entre os poderes. De forma que seja possível a implementação dos direitos fundamentais dentro dos Tribunais bem como o controle da inércia inconstitucional dos demais poderes. Nessa mesma esteira, segue o ministro do STF, no Brasil, Luís Roberto Barroso:

O fato inafastável é que a interpretação jurídica, nos dias atuais, reserva para o juiz papel muito mais proativo, que inclui a atribuição de sentido a princípios abstratos e conceitos jurídicos indeterminados, bem como a realização de ponderações. Para além de uma função puramente técnica de conhecimento, o intérprete judicial integra o ordenamento jurídico com suas próprias valorações, sempre acompanhadas do dever de justificação. Discricionariedade judicial, portanto, traduz o reconhecimento de que o juiz não é apenas o boca da lei, um mero exegeta que realiza operações formais. 
Existe dimensão subjetiva na sua atuação. Não a subjetividade da vontade política própria - que que bem claro - , mas a que inequivocamente decorre da compreensão dos institutos jurídicos, da captação do sentimento social e do espírito de sua época. (BARROSO, 2015, p.33)

Percebe-se que o ativismo judicial é um instrumento de exercício dessa discricionariedade e que deve ser realizado com parcimônia. A proatividade judicial não pode se transmutar em um "super poder", que tudo pode e que nada teme. Pelo contrário, o ativismo judicial só pode ser dito legítimo se realizado dentro dos estritos limites da Constituição que pressupõe um dever de justificação das decisões judiciais sempre pautado no sistema constitucional.

As motivações particulares dos magistrados não possuem o condão de estabelecer o fio condutor da sociedade. O juiz, mesmo que numa atividade proativa, tem a sua liberdade restrita ao dispositivo constitucional a ser interpretado sempre com o objetivo maior de garantir a dignidade da pessoa humana por meio da efetivação dos direitos fundamentais.

Assim, o juiz possui um dever de coerência e integridade para com a Constituição, pois só nela poderá encontrar a verdade do caso concreto como bem coloca BARROSO:

Dito isso, porém, um intérprete judicial jamais poderá chegar ao final do exame de uma questão e afirmar que não há uma solução própria para ela. Vale dizer: não pode dizer que há empate, que tanto faz um resultado ou outro, ou que o caso pode ser decidido por cara e coroa. Assim, embora não se possa falar, em certos casos difíceis, em uma resposta objetivamente correta — única e universalmente aceita —, existe, por certo, uma resposta subjetivamente correta. Isso significa que, para um dado intérprete, existe uma única solução correta, justa e constitucionalmente adequada a ser perseguida. E esse intérprete tem deveres de integridade - ele não pode ignorar o sistema jurídico, os conceitos aplicáveis e os precedentes na matéria - e tem deveres de coerência, no sentido de que não pode ignorar as suas próprias decisões anteriores, bem como as premissas que estabeleceu em casos precedentes. Um juiz não é livre para escolher de acordo com seu estado de espírito, suas simpatias ou suas opções estratégicas na vida. Um juiz de verdade, sobretudo um juiz constitucional, tem deveres de integridade e de coerência. (BARROSO, 2015, p.35)

Diante disso, o Judiciário tem exercido importante papel de força contramajoritária no que tange à defesa dos direitos fundamentais, principalmente, com o intuito de promover uma maior igualdade entre os indivíduos em sociedade, como por exemplo:

No Brasil, o Supremo Tribunal Federal equiparou as uniões homoafetivas às uniões estáveis convencionais, abrindo caminho para o casamento entre pessoas do mesmo sexo. Talvez esta não fosse posição majoritária na sociedade, mas a proteção de um direito fundamental à igualdade legitimava a atuação. Semelhança temente se passou com a permissão para a interrupção da gestação de fetos anencefálicos. São exemplos emblemáticos do papel iluminista da jurisdição constitucional. Nesses dois casos específicos, um fenômeno chamou a atenção. Em razão da natureza polêmica dos dois temas, uma quantidade expressiva de juristas se posicionou contrariamente às decisões — "não por serem contrários ao mérito, absolutamente não...” —, mas por 
entenderem se tratar de matéria da competência do legislador, e não do STF. Como havia direitos fundamentais em jogo, esta não parece ser a melhor posição. Ela contrapõe o princípio formal da democracia — as maiorias políticas é que têm legitimidade para decidir — aos princípios materiais da igualdade e da dignidade da pessoa humana, favorecendo o primeiro em ambos os casos. Coloca-se o procedimento acima do resultado, o que não parece um bom critério. (BARROSO, 2015, p. 42)

De fato, as situações supramencionadas deveriam serem reguladas pelo Poder Legislativo, porém quando o parlamento se omite - quiçá propositalmente - os direitos fundamentais dos sujeitos envolvidos nos conflitos sociais não regulamentados devem ser sacrificados?

Parece que não é esse o intento dos Estados Constitucionais, uma vez que possuem como fundamento o princípio da dignidade da pessoa humana que significa a proteção de todo e qualquer ser humano, seja ele parte das maiorias ou minorias.

Logo, o Poder Judiciário atuará justamente na garantia dos direitos fundamentais, principalmente, quando há omissão dos poderes políticos do estado. A referência pejorativa, portanto, feita por grande parcela da doutrina, ao fenômeno do ativismo judicial, por si só, não se justifica.

Ressalte-se que a atuação abusiva do Poder Judiciário sempre deve ser responsabilizada, em especial, quando realizada no sentido de usurpar as funções políticas dos demais poderes. Afinal, uma falha política jamais pode ser usada como justificativa de uma falha jurídica.

\section{CONCLUSÃO}

Diante o exposto, percebe-se que a função judiciária no século XXI deixou de ser entendida como restrita à reprodução legal. Hoje, vivenciamos uma mudança de paradigma da função judiciária a partir da necessidade de reconhecer a legitimidade da discricionariedade judicial.

Objetivou-se demonstrar que a discricionariedade judicial é uma função intrínseca do Poder Judiciário que com a abertura constitucional que ocorreu no final do século XX, no pósguerras, encontrou campo propício para seu fortalecimento. Partiu-se, portanto, da teoria da força normativa da Constituição para justificar a necessidade de atribuir imperatividade ao documento constitucional para que pudesse ter maior efetividade diante das demandas sociais.

Afinal, a força normativa da Constituição significa que a norma suprema passa de 
mero norte político para norma jurídica cogente e imperativa o que lhe permite estabelecer uma relação dialógica com a sociedade, resultando em uma maior vinculação "às forças espontâneas e às tendências dominantes do seu tempo", possibilitando um maior desenvolvimento uma ordem mais efetiva no que tange à regulação social.

Assim, intentou-se demonstrar que a relação dialógica entre a Constituição e a soiedade só é possível a partir do efetivo cumprimento da Constituição que se faz pela consecução das atribuições das funções primordiais dos poderes do Estado: Legislativo, Executivo e Judiciário.

O exercício de tais funções como já preconizado por Montesquieu, deve se dar de forma independente e equilibrada. Ora, diante da crise de representatividade dos poderes políticos pela qual passa grande parte do globo enquanto sociedade que decorre, justamente, da ausência de identidade entre a vontade popular e a vontade manifestada pelo Executivo e Legislativo no estabelecimento dos atos públicos e leis, a Constituição tende a perder sua força normativa.

Por isso, o presente trabalho discute acerca da legitimidade da discricionariedade judicial como meio para restabelecer o equilíbrio entre os poderes e efetivar a máxima do checks and balances e promover a garantia de direitos fundamentais.

Ficou demonstrado que a partir do momento em que se percebe que o Poder Executivo e o Poder Legislativo, por inércia ou omissão inconstitucional, concorrem para a ineficácia de direitos fundamentais e, por consequência, das liberdades públicas, a relação de reciprocidade entre a Constituição e a sociedade resta prejudicada.

A atuação proativa do Judiciário vem em resposta a esse enfraquecimento da Constituição, na tentativa de reestabelecer os pesos e contrapesos entre os poderes estatais. Contudo, é importante ressaltar que tal proatividade judicial deve seguir os limites impostos pelo sistema constitucional como restou demonstrado.

Jamais a discricionariedade judicial deve ser utilizada como justificativa para imposição de interesses particulares por meio da atuação do Poder Judiciário. Essa, por sinal tem sido a principal crítica e a justificativa para o tratamento pejorativo dado ao fenômeno do ativismo judicial.

Todos os poderes do estado têm sua atuação limitada à Constituição, em especial, aos direitos fundamentais. Com o Judiciário, ocorre o mesmo. Logo, para a discricionariedade judicial ser legítima, é necessário que a decisão judicial siga fielmente os limites impostos pelo 
sistema constitucional.

Desta feita, acredita-se que o ativismo judicial não constitui um mal por si só à teoria da separação dos poderes. Pelo contrário, tal fenômeno quando realizado dentro dos limites da Constituição com o fim de promover sua maior efetividade, em especial, de dar maior efetividade dos direitos fundamentais, constitui forte aliado.

\section{REFERÊNCIAS}

AFONSO, Orlando Viegas Martins. Poder Judicial: Independência in Dependência. Lisboa: Editora Almedina, 2004.

AZAMBUJA, Darcy. Teoria Geral do Estado. 4 ed. rev. ampl. e atual.. São Paulo: Globo, 2008.

BARROSO, Luís Roberto. A razão sem voto: o Supremo Tribunal Federal e ao governo da maioria. Revista Brasileira de Politicas Públicas. V.5, número especial, p 24-48, 2015. Disponível em: http://publicacoesacademicas.uniceub.br. Acesso em: 01 de março de 2017.

BARROSO, Luís Roberto. Curso de Direito Constitucional Contemporâneo: os conceitos fundamentais e a constituição do novo modelo. 3 ed. São Paulo: Saraiva, 2011.

BARROSO, Luís Roberto. Judicialização, Ativismo Judicial e Legitimidade Democrática. Revista Seleções Jurídicas. COAD: Rio de Janeiro, 2009

BOBBIO, Noberto. A Era dos Direitos. Rio de Janeiro: Elsevier, 2004.

BONAVIDES, Paulo. Teoria Geral do Estado. 8 ed.. São Paulo: Malheiros, 2010.

BONAVIDES, Paulo. Curso de Direito Constitucional. 14 ed.. São Paulo: Malheiros, 2004.

CAPPELLETTI, Mauro. Juízes Legisladores? Trad. Carlos Alberto Álvaro de Oliveira. Porto Alegre: Sérgio Antonio Fabris Editor, 1993.

COELHO, Inocêncio Mártires. Apontamentos para um debate sobre ativismo judicial .

Revista Brasileira de Politicas Públicas. V.5, número especial, p 03-24, 2015. Disponível em: http://publicacoesacademicas.uniceub.br. Acesso em: 01 de março de 2017.

HESSE, Konrad. A força normativa da Constituição. Porto Alegre: Sérgio Antonio Fabris Editor, 1991

MONTESQUIEU (1689-1755). Do espírito das leis. Trad. Roberto Leal Ferreira. São Paulo: Martin Claret, 2010.

NOVAIS, Jorge Reis. A dignidade da pessoa humana. vol. I. Lisboa: Almedina, 2015. PIRES, Alex Sander Xavier Pires. Súmula Vinculante e liberdades fundamentais. Rio de 
Janeiro: Pensar a Justiça, 2016

RAMOS, Paulo Roberto Barbosa. Federalismo e descentralização territorial em perspectiva comparada: os sistemas do Brasil e da Espanha. Porto Alegre: Sérgio Antônio Fabris Ed., 2012.

TOCQUEVILLE, Alexy. A Democracia na América. 2 ed.. Belo Horizonte: Ed. Itatiaia, 1998. 